\title{
Characterisation of Pinus canariensis C.Sm. ex DC. Sawn Timber from Reforested Trees on the Island of Tenerife, Spain
}

\author{
Luis García Esteban ${ }^{1, *(\mathbb{D})}$, Paloma de Palacios ${ }^{1}{ }^{\mathbb{D}}$, Francisco García Fernández ${ }^{1}{ }^{(0)}$, \\ Alberto García-Iruela ${ }^{1}$ (D), Juan Carlos del Pozo ${ }^{1}$, Víctor Pérez Borrego ${ }^{2}$, Juan Agulló Pérez ${ }^{2}$, \\ Eva Padrón Cedrés ${ }^{2}$ and Francisco Arriaga ${ }^{3}$ (D) \\ 1 Cátedra de Tecnología de la Madera, Departamento de Sistemas y Recursos Naturales, Escuela Técnica \\ Superior de Ingeniería de Montes, Forestal y del Medio Natural, Universidad Politécnica de Madrid, \\ Ciudad Universitaria, 28040 Madrid, Spain; paloma.depalacios@upm.es (P.d.P.); \\ francisco.garcia@upm.es (F.G.F.); agiruela17@gmail.com (A.G.-I.); juancarlos.pozo@upm.es (J.C.d.P.) \\ 2 Servicio Técnico de Planificación y Proyectos Forestales, Área de Sostenibilidad, Medio Ambiente y \\ Seguridad, Cabildo Insular de Tenerife, Las Macetas s/n, Pabellón Insular Santiago Martín, Los Majuelos, \\ 38108 San Cristóbal de La Laguna, Spain; victor@tenerife.es (V.P.B.); jagullo@tenerife.es (J.A.P.); \\ evap@tenerife.es (E.P.C.) \\ 3 Cátedra de Cálculo de Estructuras, Departamento de Ingeniería y Gestión Forestal y Ambiental, \\ Escuela Técnica Superior de Ingeniería de Montes, Forestal y del Medio Natural, Universidad Politécnica de \\ Madrid, Ciudad Universitaria, 28040 Madrid, Spain; francisco.arriaga@upm.es \\ * Correspondence: luis.garcia@upm.es
}

Received: 30 May 2020; Accepted: 15 July 2020; Published: 17 July 2020

\begin{abstract}
Canary Island pine (Pinus canariensis C.Sm. ex DC) is a species endemic to the Canary Islands (Spain) that was for centuries overexploited for its wood and resin. Due to the state of the pine forest, more than 10,000 hectares were reforested in the middle of the 20th century. Now, under the silvicultural management plan, thinning operations have allowed Canary Island pine wood to be mechanically characterised for the first time using large test pieces. In total, 1529 pieces measuring $2600 \times 120 \times 35 \mathrm{~mm}$ and visually graded according to Spanish standard UNE 56544 (Visual grading of large structural coniferous sawn timber) were assessed, resulting in 872 pieces in grades ME- 1 and ME-2 and 657 rejects. After the characteristic values of density $\left(479-453 \mathrm{~kg} \cdot \mathrm{m}^{-3}\right)$, modulus of elasticity (MOE) $\left(14,023-11,276 \mathrm{~N} \cdot \mathrm{mm}^{-2}\right)$ and bending strength (MOR) $\left(26-14 \mathrm{~N} \cdot \mathrm{mm}^{-2}\right)$ were determined for both grades (ME-1 and ME-2), strength class C24 was assigned to grade ME-1, with similar values to Pinus radiata D.Don and Pinus pinaster Aiton, and C14 was assigned to grade ME-2. Density, number of growth rings, growth ring width, and presence/absence of resinous wood have a significant influence on MOE and MOR, for a confidence level of $95 \%$. Reforestation of Canary Island pine not only allows restoration of the forest cover, but also provides an opportunity, through thinning, to obtain quality wood, helping to create employment and associated industry. This local example with an endemic species can be extrapolated to other parts of the world.
\end{abstract}

Keywords: Pinus canariensis; structural timber; strength classes; growth rings; resinous wood

\section{Introduction}

Pinus canariensis C.Sm. ex DC (Canary Island pine) is naturally distributed on five islands of the Canary Islands archipelago: Gran Canaria, Tenerife, La Gomera, El Hierro and La Palma. The largest area of pine forest $(41,210 \mathrm{ha})$ is on Tenerife (Figure 1$)$ and includes the 20th century plantations, followed by La Palma (23,000 ha), Gran Canaria (11,000 ha) and El Hierro (2700 ha) [1,2]. 


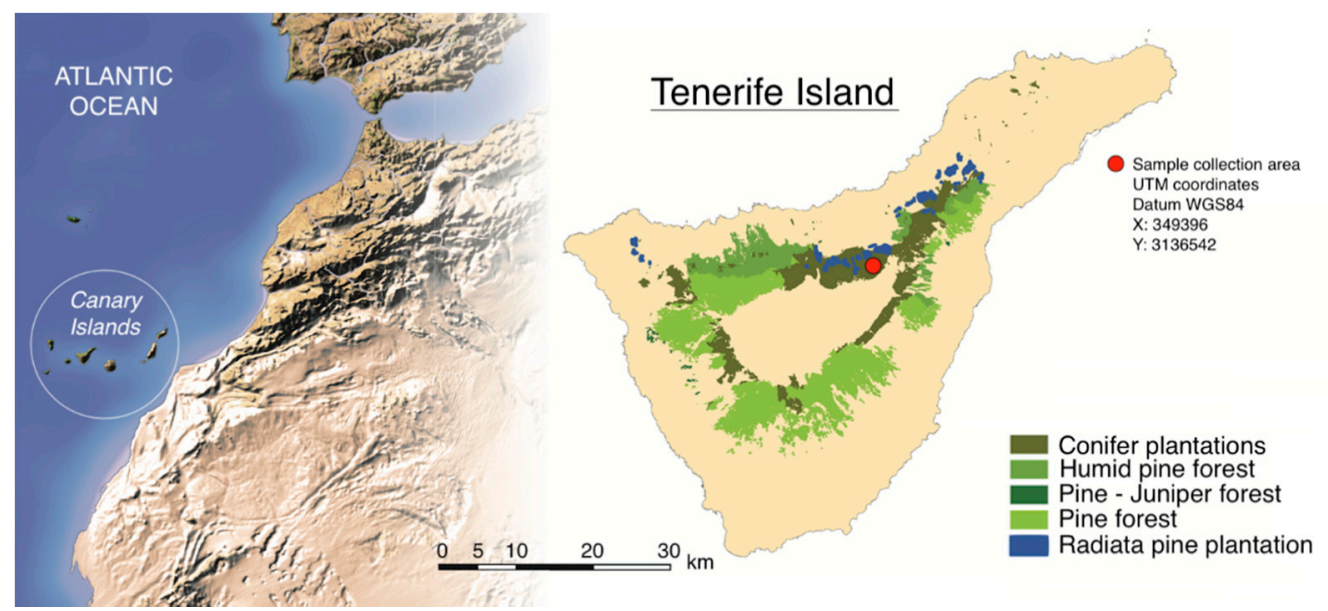

Figure 1. Distribution of pine forests on the island of Tenerife. Based on a map from Área de Sostenibilidad, Medio Ambiente, Aguas y Seguridad, Cabildo de Tenerife.

Most of the main forests on Tenerife are included in the Natura 2000 Network and are habitats of community interest that are home to many species classified in various figures of protection. In many cases they are species endemic to Macaronesia, the Canary Islands or to Tenerife itself. However, the persistence and stability of more than 10,000 ha of reforested Canary Island pine trees included in protected natural areas are not guaranteed. Moreover, the Canary Islands have not passed a Regional Forest Law, which leaves a gap in the management of the region's natural and forest heritage because they currently come under the National Forest Law.

One of the challenges of sustainable forest management is to increase the value of the forest products generated by the silvicultural treatments that are necessary to improve and conserve forests. Achieving this would incorporate environmental, economic, social and cultural aspects into sustainable management, helping to conserve the natural environment, create jobs and ensure the multiple use of forests. One of the possible uses of wood that would increase its value is in structural applications.

To date, Canary Island pine wood has been mechanically characterised only with small clear test pieces taken from its natural area [3] and plantations outside the Canary Islands [4]. The presence of resinous wood, i.e., the presence of large amounts of resin in the heartwood, endows this timber with rot resistance that makes it very suitable for exterior carpentry [5].

This wood has been used since the 16th century for firewood, naval and civil construction, exterior and interior carpentry (Figure 2a-c), manufacture of pitch to caulk ships, furniture making, floors, barrels for wine ageing, and manufacture of agricultural tools and domestic utensils, among other uses. Many trunks still bear the scars of wounds made by pitch manufacturers to test the tree for resin production. Wounds provide an easy pathway for fire to attack trees. Deprived of the protection of their bark during attack from fire, trees die and can smoulder for months (Figure 2d). Local sugar mills required large amounts of fuel to produce molasses, and destroyed a considerable part of the forests in the archipelago. Pine forests originally occupied about $25 \%$ of the islands' territory, but after centuries of attacks, their area of extent was reduced to just $12 \%$ by the late 19th century. Centuries of uncontrolled exploitation brought an end to centuries-old forests. Photos of places such as the Orotava valley and areas near Mount Teide show the pitiful state of the forest in the early 20th century (Figure 2e). These images differ greatly from the forest cover today after a long process of reforestation that started in the second half of the 20th century (Figure 2f). From 1946 to 1970, State Forest Heritage replanted around 11,600 hectares, mostly on the island of Tenerife (Figure 2g). The initial stand density for reforestation was around 1000 individuals per hectare. This high number was to ensure the viability of a large number of individuals and subsequent thinning. The silvicultural plan aims to leave 600 individuals after the first thinning and 250-400 after the second, not because of economic plans, but to restore the forest cover of the Canary Island pine forests. More than 60 years 
later, plantations are now being thinned to leave the best individuals [2]. Thinning will bring Canary Island pine wood back into use, particularly for construction, creating an opportunity to meet the challenges posed by sustainable forest management.
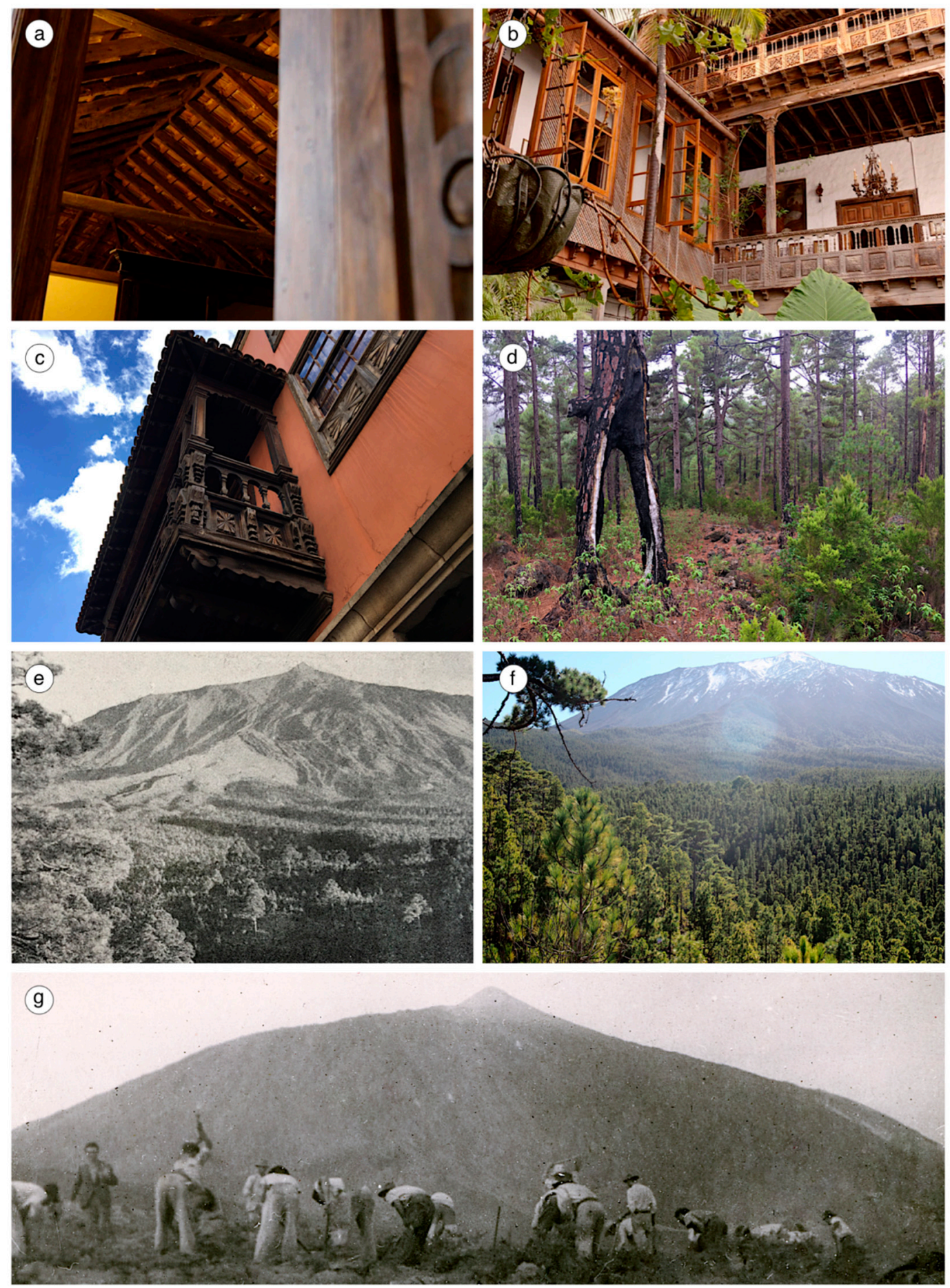

Figure 2. $(\mathbf{a}-\mathbf{c})$ Constructions made from Canary Island pine wood in the municipality of La Orotava (Tenerife). Casa de Los Balcones, 17th century. (a) Wooden ceiling structure; (b) exterior carpentry and wooden balcony; (c) typical wooden balconies; (d) Canary Island pine wounded to obtain pitch for caulking ships and subsequently affected by fire; (e) Icod Pine Forest, 1951 (Fototeca Forestal Española DGB-INIA (Ref. 418) [6]); (f) Icod Pine Forest, 2019 (Photo by Javier León); (g) plantations in Mount Teide forest, 1951 (Montse Quintero photographic archive). 
Logs from trees felled during current thinning in reforested areas of Tenerife have permitted structural characterisation of Canary Island pine wood. This is one of the Spanish pines still to be characterised and is therefore not included in current standards.

The objectives of this study were: (1) to determine the characteristic values of bending strength, modulus of elasticity and density of Canary Island pine wood; (2) to propose a visual grading criterion based on standard UNE 56544 [7]; (3) to assign visual grades to a strength class according to standard EN 338 [8]; and (4) to determine the influence of density, number of growth rings, growth ring width and presence of resinous wood on bending strength and modulus of elasticity.

\section{Materials and Methods}

\subsection{Sample Collection and Preparation}

The site available for sample collection was in Public Utility Forest "MUPc 22 Mamio, Leres y Monteverde", located in the municipality of La Orotava on the island of Tenerife (Figure 1), at a mean altitude of $1440 \mathrm{~m}$.

Trees from the first scheduled thinning (Figure 3) were selected from individuals representative of the forest with a diameter of $31-40 \mathrm{~cm}$ at the base that had not been influenced by the edge effect. The 263 logs collected, $2600 \mathrm{~mm}$ in length, yielded a felling volume of $50.53 \mathrm{~m}^{3}$, with 122 corresponding to first logs and 141 to second logs. Samples were marked with numbers 1 and 2 in the forest according to their position in the log and this code was maintained until sample preparation. According to EN 384 standard [9], sample is defined as a number of ungraded specimens of one timber species or species combination, one source, with sizes and quality representative of the timber population, and sub-sample is defined as part of one or more samples consisting of specimens of one grade.

Boles were plain-sawn to $40 \mathrm{~mm}$ thickness (Figure 3e) and edged to $120 \mathrm{~mm}$ width. Pieces were air dried for one month to decrease the humidity percentage (Figure 3f), then kiln dried to around $12 \%$.

Once in the laboratory, samples were planed in a thicknessing machine to $35 \mathrm{~mm}$ and kept in a conditioning chamber at $20 \pm 2{ }^{\circ} \mathrm{C}$ and $65 \pm 5 \%$ relative humidity until testing to keep them at around $12 \%$ moisture content. 

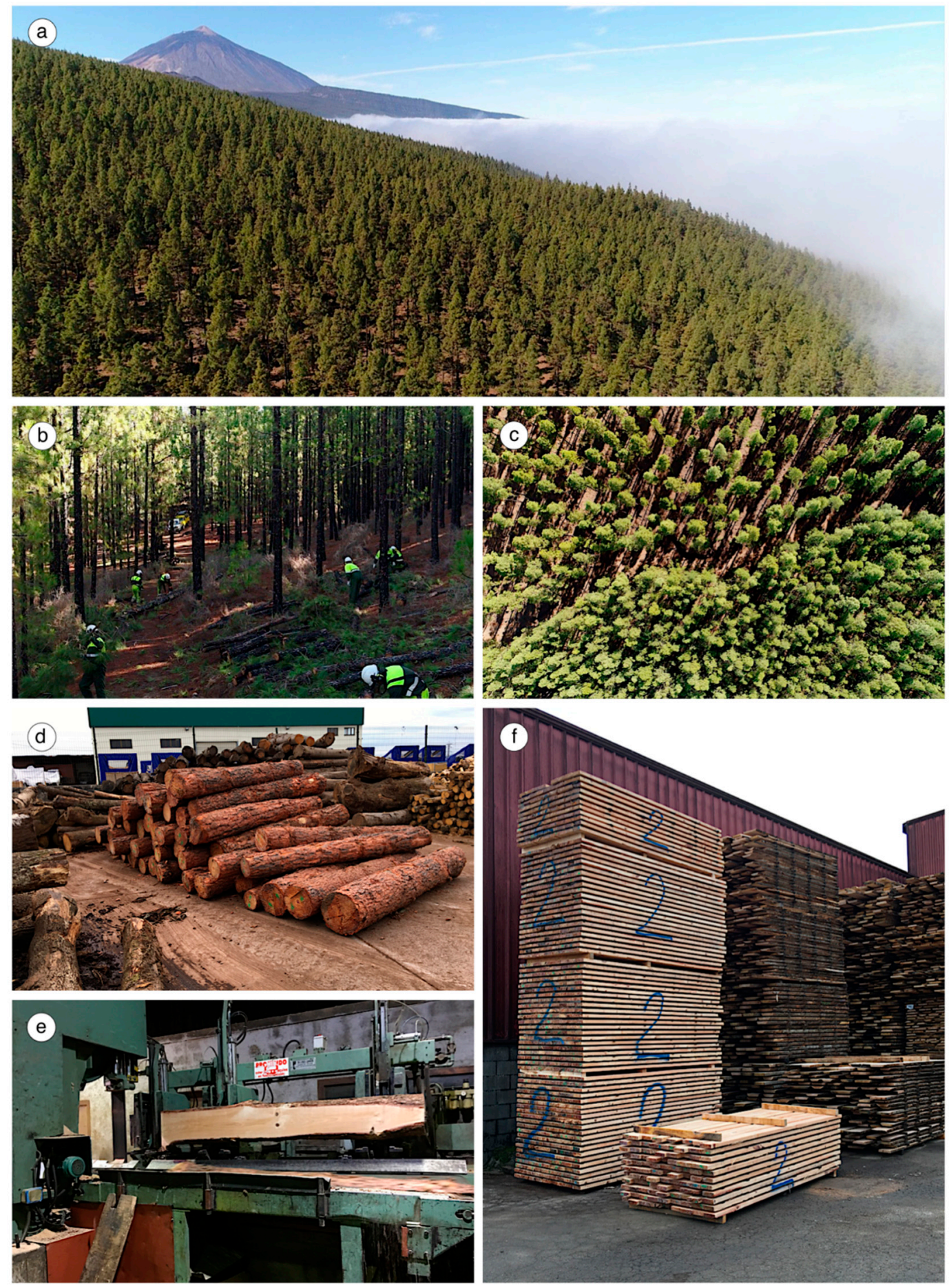

Figure 3. Sample collection. (a) Canary Island pine forest on the north slope; (b) plantation thinning tasks; (c) plantation with and without thinning; (d) boles in the sawmill yard; (e) sawing boles; (f) stacks of sawn timber from $\log 2$.

\subsection{Visual Strength Grading}

For visual strength grading of the test pieces, the grading criteria followed were those included in UNE 56544 [7] (Table 1), which applies to the main Spanish structural coniferous timbers. This standard grades structural wood with a maximum width of $70 \mathrm{~mm}$ into two grades (ME-1, ME-2) by defects (knots, fissures, ring shakes and resin pockets). Pieces that did not fall into these grades were considered rejects and were therefore excluded. 
Table 1. Visual grading specifications from Spanish standard UNE 56544 [7] for coniferous sawn timber of a rectangular cross-section and a width $\mathrm{b} \leq 70 \mathrm{~mm}$.

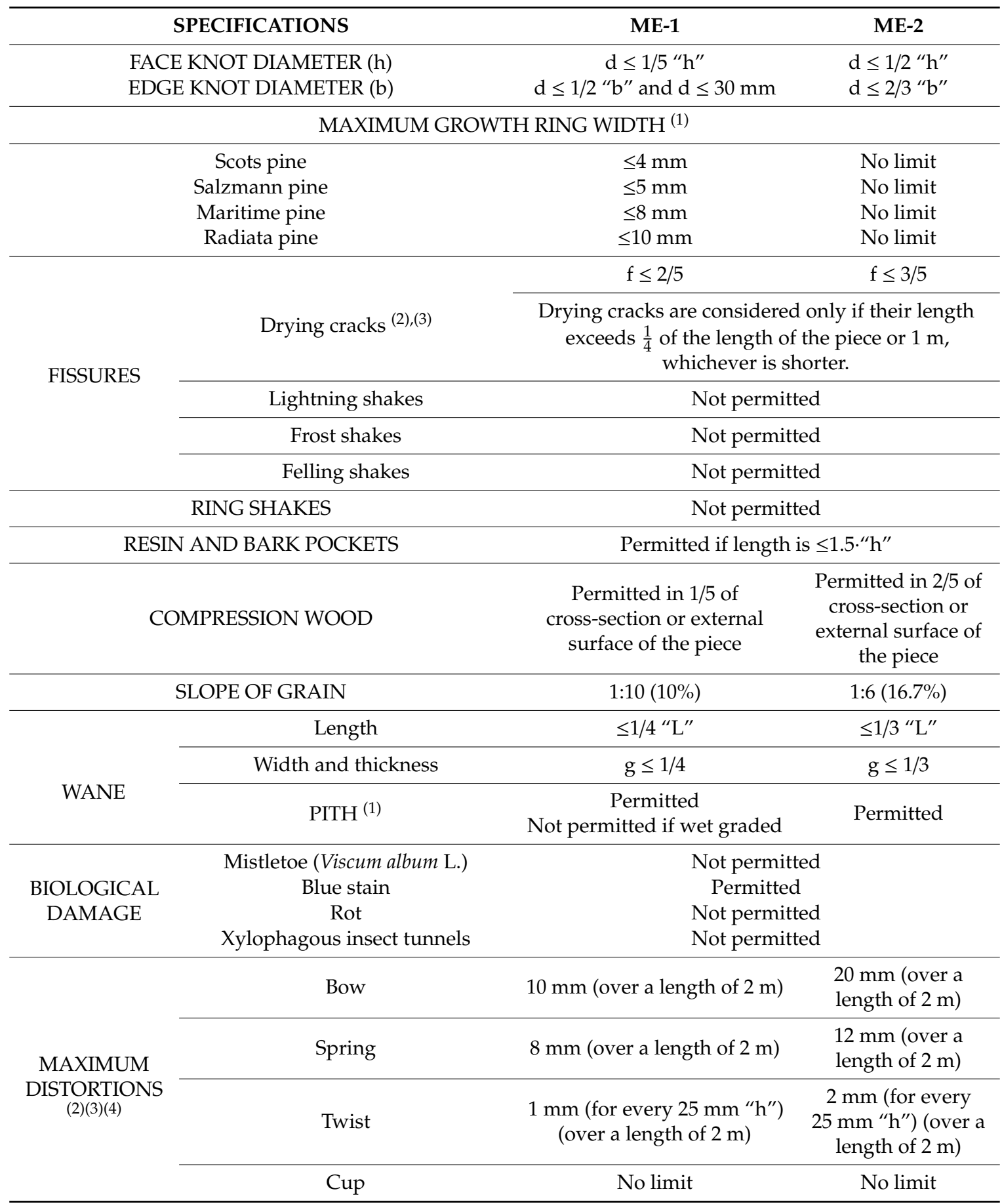

(1) Applicable only when timber is sold wet; ${ }^{(2)}$ not applicable to wet grading; ${ }^{(3)}$ in reference to $20 \%$ moisture content; (4) larger distortions can be accepted provided they do not affect the stability of the construction (because they can be corrected during erection) and the supplier and the client have an express agreement to that effect. Scots pine-Pinus sylvestris L.; Salzmann pine-Pinus nigra Arnold ssp. salzmannii (Dunal) Franco; Maritime pine—Pinus pinaster Aiton; Radiata pine—Pinus radiata D.Don. Symbols—f: fissure depth; L: piece length; $\mathrm{g}$ : wane dimension in width or thickness; $\mathrm{h}$ test piece depth in $\mathrm{mm}$.

Pieces were measured following standard EN 1309-1 [10] and the wood features included in Table 1 of UNE 56544 [7] were measured according to EN 1309-3 [11]. A total of 1529 pieces $(2600 \times 120 \times 35 \mathrm{~mm}-1 \times \mathrm{h} \times \mathrm{b})$ were classified. 


\subsection{Physical and Mechanical Properties}

For each piece, moisture content was determined according to standard EN 13183-1 [12,13] and density was determined according to EN 408 [14] immediately after rupture, using a full cross-section slice free of knots and resin pockets as close as possible to the rupture zone and as far as possible from the ends.

Moisture content and unextracted density (12\%) were determined using a Cobos CB-600 balance (0-600 g, $0.01 \mathrm{~g}$ scale division), a Memmert D06836 oven $\left(0-250{ }^{\circ} \mathrm{C}, 0.1{ }^{\circ} \mathrm{C}\right.$ scale division), and a Mitutoyo Digimatic digital calliper ( $250-300 \mathrm{~mm}, 300 \mathrm{~mm}$ scale division).

Bending strength and global modulus of elasticity were calculated according to EN 408, Sections 10 and 19 [14]. A Microtest universal testing machine with a load cell of $40 \mathrm{kN}$ and class 1 was used. Maximum deformation during testing was measured using an external linear variable differential transformer (LVDT) with $0.001 \mathrm{~mm}$ scale division (Figure 4a).

(a)
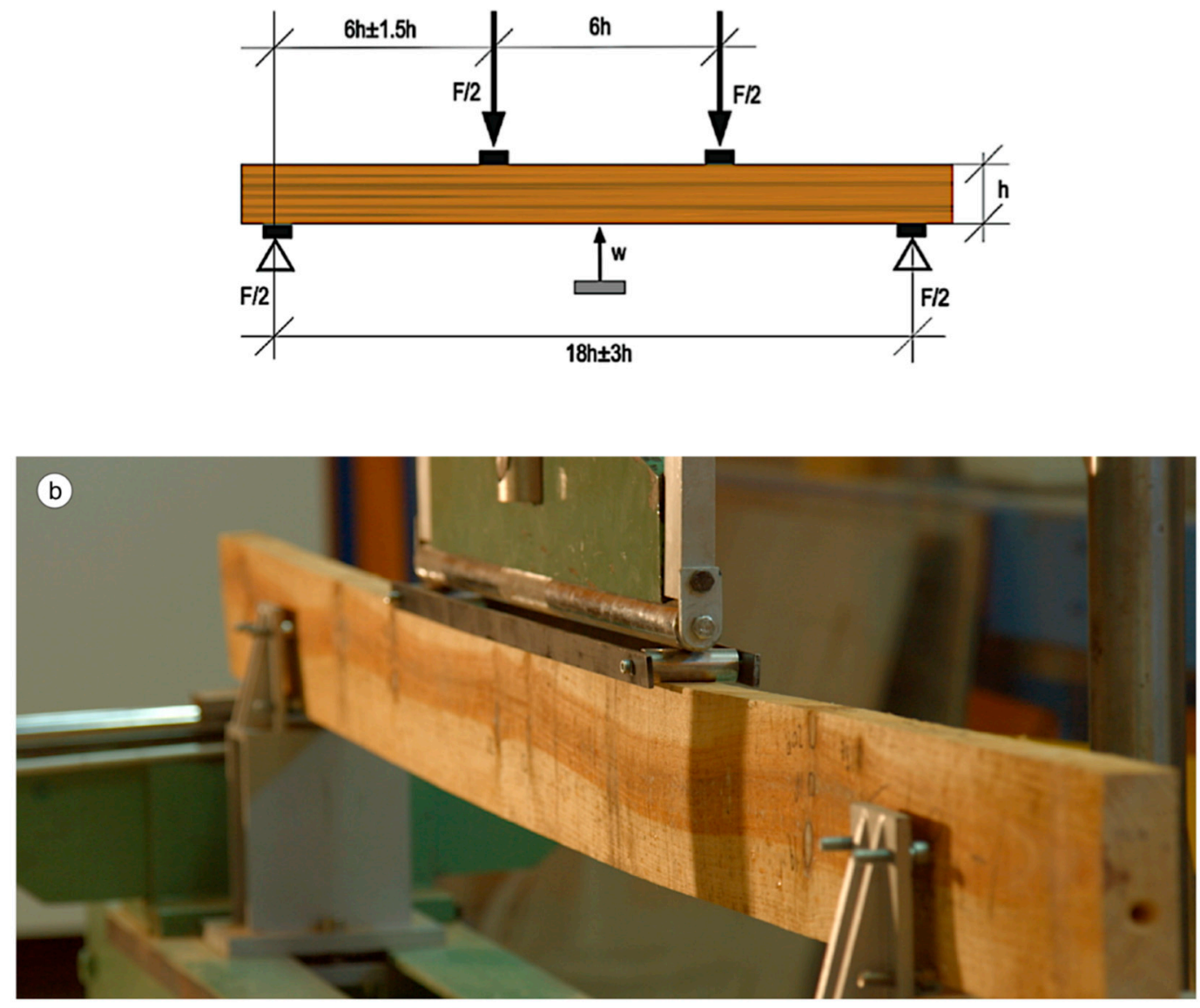

Figure 4. Bending test. (a) Diagram of EN 408 test [14] to determine modulus of elasticity (F: load applied, h: depth of cross-section, w: deformation); (b) piece under load.

\subsection{Reference Conditions and Adjustment Factors}

Although all samples were conditioned to $20 \pm 2{ }^{\circ} \mathrm{C}$ and $65 \pm 5 \%$, the results were adjusted after testing to the reference moisture content of $12 \%$ according to the moisture content at the time of testing, in accordance with EN 384 Sections 5.3 and 5.4 [9] (Equations (1) and (2)).

$$
\begin{gathered}
\mathrm{E}_{0}=\mathrm{E}_{0}(\mathrm{u}) \times\left(1+0.01 \times\left(\mathrm{u}-\mathrm{u}_{\mathrm{ref}}\right)\right) \\
\rho=\rho(\mathrm{u}) \times\left(1+0.005 \times\left(\mathrm{u}-\mathrm{u}_{\mathrm{ref}}\right)\right)
\end{gathered}
$$


where

$\mathrm{E}_{0}$ : modulus of elasticity in the bending parallel to grain;

$\rho:$ density;

$\mathrm{u}$ : moisture content at the time of testing;

$\mathrm{u}_{\text {ref: }}$ : reference moisture content $(12 \%)$.

Bending strength results were adjusted to a $150 \mathrm{~mm}$ reference depth, because EN 384 Section 5.3 [9] specifies that for depths less than $150 \mathrm{~mm}$ and densities of $700 \mathrm{~kg} \cdot \mathrm{m}^{-3}$ or less, bending strengths must be divided by correction factor $k_{h}$ (Equation (3)).

$$
k_{h}=\operatorname{Min}\left\{\begin{array}{c}
\left(\frac{150}{h}\right)^{0.2} \\
1.3
\end{array}\right.
$$

where $\mathrm{h}$ is the test piece depth in $\mathrm{mm}$.

Because the global modulus of elasticity in bending was obtained, the adjustment indicated in EN 384 Section 5.4.4 [9] was applied to determine modulus of elasticity parallel to the grain (Equation (4)).

$$
\mathrm{E}_{0}=\mathrm{E}_{\mathrm{m}, \mathrm{global}\left(\mathrm{u}_{\text {ref }}\right)} \times 1.3-2690
$$

where

$\mathrm{E}_{0}$ : modulus of elasticity in the bending parallel to grain (free of the shear effect);

$\mathrm{E}_{\mathrm{m}, \text { global(uref) }}$ : global modulus of elasticity.

\subsection{Characteristic Values}

For each sub-sample (i) visually graded, the 5-percentile value of bending strength $\mathrm{F}_{05, \mathrm{i}}$ and the 5 -percentile value of density $\rho_{05, i}$ were obtained, following standard EN 14358 [15]. The mean value of modulus of elasticity $\bar{E}_{i}$ of each subsample was obtained using the same standard.

To address levels of confidence, the characteristic 5-percentile values are used in the ultimate limit state, as in strength verifications, and the characteristic mean values correspond to the 50-percentile in a normal distribution and are used in service limit state verification, as in deformation limits.

The characteristic values of strength (5-percentile), modulus of elasticity (50-percentile) and density (5-percentile) were determined using Equations (5)-(7), following EN 384 Section 5.5.2.2 [9].

$$
\begin{gathered}
\mathrm{f}_{\mathrm{k}}=\min \left(1.2 \times \mathrm{f}_{05, \mathrm{i}, \mathrm{min}}, \frac{\sum_{\mathrm{i}=1}^{\mathrm{ns}} \mathrm{n}_{\mathrm{i}} \times \mathrm{f}_{05, \mathrm{i}}}{\mathrm{n}}\right) \times \mathrm{k}_{\mathrm{n}} \\
\mathrm{E}_{0, \text { mean }}=\min \left(1.1 \times \overline{\mathrm{E}}_{\mathrm{i}, \min }, \frac{\sum_{\mathrm{i}=1}^{\mathrm{ns}} \mathrm{n}_{\mathrm{i}} \times \overline{\mathrm{E}}_{\mathrm{i}}}{\mathrm{n}}\right) \times \mathrm{k}_{\mathrm{n}} / 0.95 \\
\rho_{\mathrm{k}}=\min \left(1.1 \times \rho_{05, \mathrm{i}, \min } \frac{\sum_{\mathrm{i}=1}^{\mathrm{ns}} \mathrm{n}_{\mathrm{i}} \times \rho_{05, \mathrm{i}}}{\mathrm{n}}\right) \times \mathrm{k}_{\mathrm{n}}
\end{gathered}
$$

where:

$\mathrm{f}_{\mathrm{k}}$ : characteristic value of strength (5-percentile);

$\mathrm{E}_{0, \text { mean }}$ : mean characteristic modulus of elasticity (50-percentile);

$\rho_{\mathrm{k}}$ : characteristic density (5-percentile);

$f_{05, i}: 5$-percentile value of strength of sub-sample $i$;

$\mathrm{f}_{05, \mathrm{i}, \mathrm{min}}$ : lowest 5 -percentile value of strength of $\mathrm{i}$-sub-samples;

$\overline{\mathrm{E}}_{\mathrm{i}}$ : mean value of modulus of elasticity of sub-sample $\mathrm{i}$;

$\overline{\mathrm{E}}_{\mathrm{i}, \mathrm{min}}$ : lowest mean value of modulus of elasticity of i-sub-samples;

$\rho_{05, i}: 5$-percentile value of density of sub-sample i;

$\rho_{05, \mathrm{i}, \mathrm{min}}$ : lowest mean value of 5 -percentile value of density of i-sub-samples;

$\mathrm{n}_{\mathrm{s}}$ : number of sub-samples; 
$\mathrm{n}_{\mathrm{i}}$ : number of test pieces of sub-sample $\mathrm{i}$;

$\mathrm{n}$ : total number of test pieces;

$\mathrm{k}_{\mathrm{n}}$ : adjustment factor obtained by number of sub-samples (Table 2).

Table 2. Factor for adjusting the results of the tests by the number of sub-samples.

\begin{tabular}{cccccc}
\hline Number of Sub-Samples & $\mathbf{1}$ & $\mathbf{2}$ & $\mathbf{3}$ & $\mathbf{4}$ & $\mathbf{\geq 5}$ \\
\hline $\mathrm{k}_{\mathrm{n}}$ for modulus of elasticity and density & 0.88 & 0.91 & 0.94 & 0.97 & 1.00 \\
$\mathrm{k}_{\mathrm{n}}$ for strength parallel to grain & 0.70 & 0.80 & 0.90 & 0.95 & 1.00 \\
\hline
\end{tabular}

All pieces were included in a single sub-sample for both ME-1 and ME-2 visual strength grades.

\subsection{Data Analysis}

The significant influences of the variables on bending strength (MOR) and modulus of elasticity (MOE) were studied using analysis of variance. In the case of the continuous variables (density and growth ring width), analysis of variance was completed with a regression fit to study the relation between these variables and MOR and MOE. For the number of growth rings and presence/absence of resinous wood, a least significant difference (LSD) analysis was performed to show the influence of these variables on MOR and MOE.

The Lilliefors test was performed to verify normality of density, MOE, MOR and ring thickness.

To analyse the data and the graphics generated, the programme Statgraphics Centurions Ver. 18.1.06 was used.

\section{Results}

\subsection{Visual Strength Grading and Characteristic Values}

Of the 1529 pieces analysed, 48 were assigned to grade ME- 1 and 824 to ME-2, and 657 were considered reject pieces.

Tables 3 and 4 show the results of the mechanical characterisation grouped into two grades according to the results of the visual strength grading. The physical and mechanical properties of rejects are not shown in this paper because they will be analysed in a later publication aimed at improving grading results.

Table 3. Results of properties corresponding to grade ME-1. $\mathrm{f}_{\mathrm{m}}$ : bending strength; $\rho$ : density; $\mathrm{E}_{0}$ : modulus of elasticity in the bending parallel to grain.

\begin{tabular}{|c|c|c|c|}
\hline \multirow{3}{*}{ ME-1 } & No. Data & \multicolumn{2}{|c|}{48} \\
\hline & Moisture Content (\%) & \multicolumn{2}{|c|}{12.1} \\
\hline & $f_{m}\left(N \cdot m^{-2}\right)$ & $\rho\left(\mathrm{kg} \cdot \mathrm{m}^{-3}\right)$ & $\mathrm{E}_{0}\left(\mathrm{~N} \cdot \mathrm{mm}^{-2}\right)$ \\
\hline Mean & 70.6 & 627.1 & $15,138.1$ \\
\hline Standard deviation & 20.3 & 51.4 & 3947.6 \\
\hline Maximum & 121.9 & 723.2 & $21,657.6$ \\
\hline Minimum & 20.1 & 506.9 & 1843.8 \\
\hline Coefficient of variation (\%) & 28.8 & 8.2 & 26.1 \\
\hline 5-percentile value & 37.7 & 544.1 & - \\
\hline Characteristic value & 26.4 & 478.8 & $14,022.7$ \\
\hline
\end{tabular}


Table 4. Results of properties corresponding to grade ME-2. $f_{m}$ : bending strength; $\rho$ : density; $\mathrm{E}_{0}$ : modulus of elasticity in the bending parallel to grain.

\begin{tabular}{|c|c|c|c|}
\hline \multirow{3}{*}{ ME-2 } & No. Data & \multicolumn{2}{|c|}{824} \\
\hline & Moisture Content (\%) & \multicolumn{2}{|c|}{12.0} \\
\hline & $\mathrm{f}_{\mathrm{m}}\left(\mathrm{N} \cdot \mathrm{mm}^{-2}\right)$ & $\rho\left(\mathbf{k g} \cdot \mathrm{m}^{-3}\right)$ & $\mathrm{E}_{0}\left(\mathrm{~N} \cdot \mathrm{mm}^{-2}\right)$ \\
\hline Mean & 47.3 & 588.5 & $12,172.5$ \\
\hline Standard deviation & 19.1 & 53.1 & 3480.1 \\
\hline Maximum & 108.4 & 919.5 & $23,588.5$ \\
\hline Minimum & 11.9 & 245.8 & 1517.1 \\
\hline Coefficient of variation (\%) & 40.3 & 9.0 & 28.6 \\
\hline 5-percentile value & 20.2 & 514.5 & - \\
\hline Characteristic value & 14.1 & 452.8 & $11,275.6$ \\
\hline
\end{tabular}

3.2. Density, Number of Growth Rings, Growth Ring Width and Presence of Resinous Wood

Table 5 shows the values of density, number of growth rings, growth ring width and number of pieces with resinous wood by visual grade.

Table 5. Density, number of growth rings, growth ring width and pieces with resinous wood by visual grade.

\begin{tabular}{cccc}
\hline & & ME-1 & ME-2 \\
\hline \multirow{3}{*}{ Density $\left(\mathrm{kg} \cdot \mathrm{m}^{-3}\right)$} & Mean & 627.1 & 588.5 \\
& Standard deviation & 51.4 & 53.1 \\
& Maximum & 723.2 & 919.5 \\
& Minimum & 506.9 & 245.8 \\
\hline \multirow{3}{*}{ Number of } & Mean & 12 & 10 \\
growth rings & Standard deviation & 2.8 & 3.1 \\
& Maximum & 19 & 26 \\
& Minimum & 7 & 5 \\
\hline \multirow{2}{*}{ Growth ring } & Mean & 3.70 & 4.41 \\
width (mm) & Standard deviation & 0.77 & 1.23 \\
& Maximum & 5.13 & 7.91 \\
& Minimum & 1.08 & 1.72 \\
\hline \multirow{2}{*}{ Resinous wood } & Presence & - & 160 \\
& Absence & 48 & 664 \\
\hline
\end{tabular}

Figure 5 shows the distribution histograms of density, number of growth rings and growth ring width by visual grade. 
ME-1

(48)
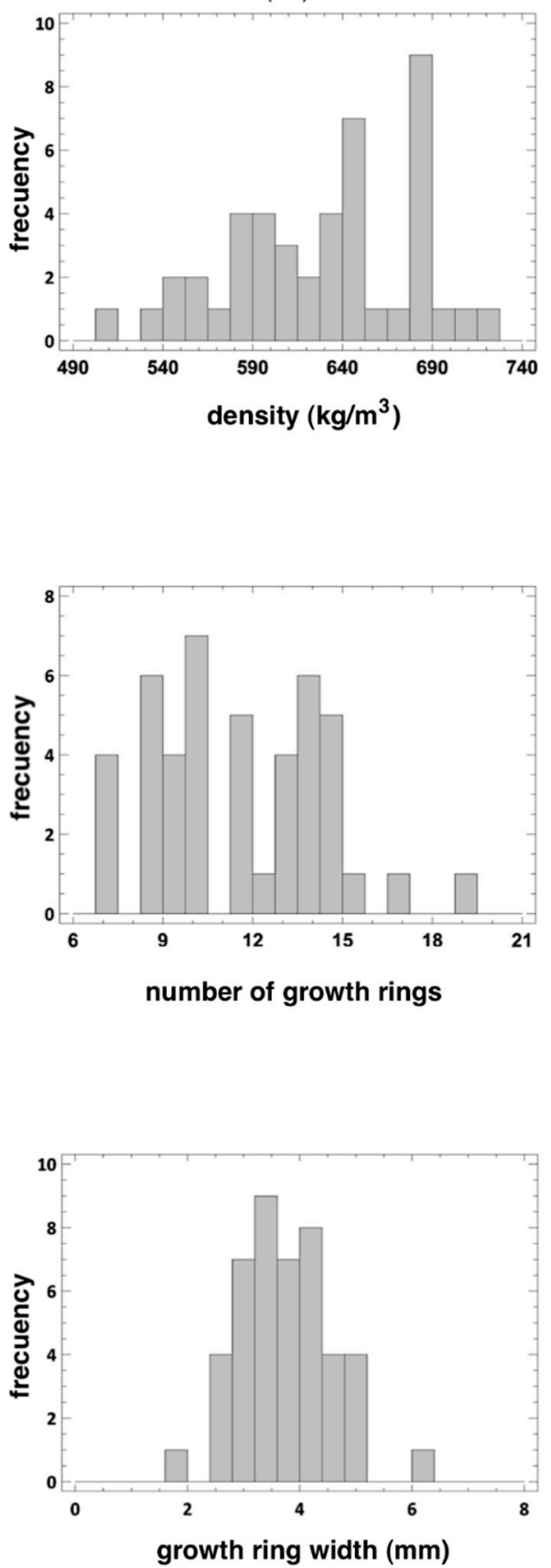

ME-2

(824)

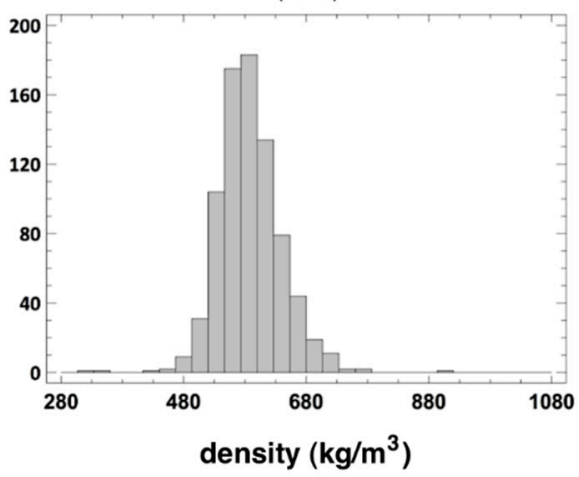

(a)

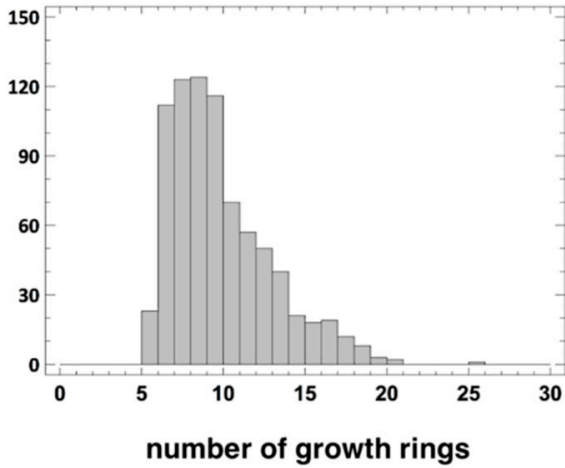

(b)

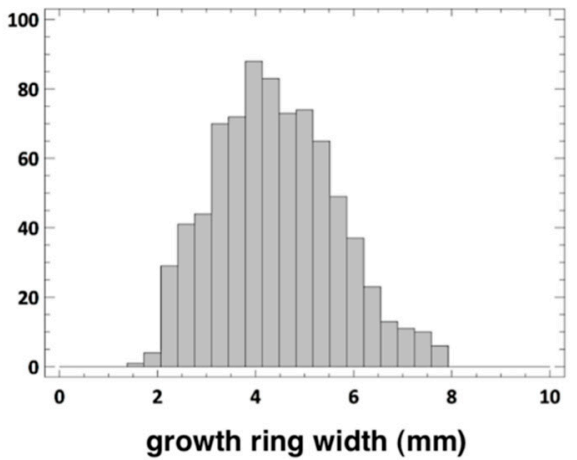

(c)

Figure 5. Distribution histograms of (a) density, (b) number of growth rings and (c) growth ring width.

\subsection{Influence of the Variables on MOR and $M O E$}

The $p$-values obtained in the corresponding ANOVA, all lower than 0.05, indicate that each variable (density, number of growth rings, growth ring width and presence of resinous wood) has a significant influence on both MOR and MOE, for a confidence level of $95 \%$.

For density, despite the low correlation coefficient obtained, there is a direct correlation $(R>0)$ between density and MOR and density and MOE. For MOR, the model proposed is capable of explaining $7 \%$ of the variability of the data, and for MOE it explains $12 \%$ (Table 6). 
Table 6. Analysis of variance and correlation between density, number of growth rings, growth ring width and presence of resinous wood; and properties of bending strength (MOR) and modulus of elasticity (MOE), grouping grades ME-1 and ME-2.

\begin{tabular}{cccccc}
\hline Property & Variable & $p$-Value & Equation & $\boldsymbol{R}$ & $\boldsymbol{R}^{\mathbf{2}}$ \\
& Density & $6.40 \times 10^{-6}$ & $M O R=-11.43+0.1 \times \rho$ & 0.27 & 0.07 \\
\multirow{4}{*}{ MOR } & Number of growth rings & $2.98 \times 10^{-24}$ & - & - & - \\
& Growth ring width & $2.58 \times 10^{-4}$ & $M O R=74.39-5.85 \times$ width & -0.37 & 0.14 \\
& Presence of resinous wood & $1.83 \times 10^{-6}$ & - & - & - \\
\hline \multirow{4}{*}{ MOE } & Density & $5.53 \times 10^{-27}$ & $M O E=-1087.15+22.62 \times \rho$ & 0.34 & 0.12 \\
& Number of growth rings & $6.25 \times 10^{-13}$ & - & - & - \\
& Growth ring width & $7.80 \times 10^{-5}$ & $M O R=18,691.6-1439.94 \times$ width & -0.51 & 0.26 \\
& Presence of resinous wood & $9.23 \times 10^{-15}$ & - & - & - \\
\hline
\end{tabular}

For growth ring width, there is an inverse relation $(R<1)$ between this variable and MOR and MOE. The models obtained are capable of explaining $14 \%$ and $26 \%$ of the variability of the data for MOR and MOE, respectively (Table 6).

The number of growth rings has a statistically significant influence on MOR and MOE (Table 6) in both visual grades (ME-1 and ME-2).

For the influence of the presence of resinous wood on MOR, grade ME- 1 was omitted because none of the pieces in this grade contained resinous wood. Analysis of the data for grade ME-2 shows two significantly differentiated homogeneous groups for both MOR and MOE (Figure 6).

\section{Resinous wood}
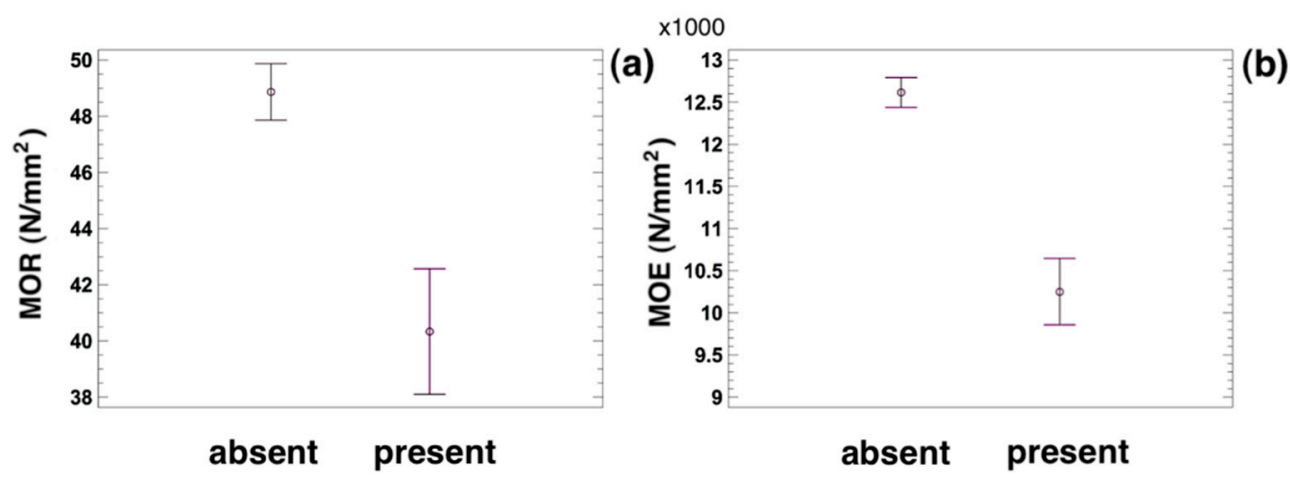

Figure 6. Least significant difference (LSD) diagrams of the influence of presence/absence of resinous wood on (a) MOR (Grade ME-2) and (b) MOE (Grade ME-2).

\section{Discussion}

The high rate of rejects (around 75\%) in the visual grading classification would presumably be at least partly due to the origin of the wood, from thinning operations rather than from trees at the end of their rotation. However, sample collection that allows selection of several sub-samples within each quality, differentiating them by taking into account altitude, soil type, orientation, etc. would permit verification of the efficiency of the visual strength grading standard for this species.

The characteristic values obtained for the properties bending strength, density and modulus of elasticity (Tables 3 and 4) allow Canary Island pine wood to be assigned according to EN 338 [8] to strength class C24 for grade ME-1 and C14 for grade ME-2. Standard EN 338 specifies that class C14 corresponds to a 5-percentile bending strength of $14 \mathrm{~N} \cdot \mathrm{mm}^{-2}$, a density of $290 \mathrm{~kg} \cdot \mathrm{m}^{-3}$ and a mean value of modulus of elasticity of $7.0 \mathrm{kN} \cdot \mathrm{mm}^{-2}$, while grade $\mathrm{C} 24$ corresponds to a 5-percentile bending strength of $24 \mathrm{~N} \cdot \mathrm{mm}^{-2}$, a density of $350 \mathrm{~kg} \cdot \mathrm{m}^{-3}$ and a mean value of modulus of elasticity of $11 \mathrm{kN} \cdot \mathrm{mm}^{-2}$. 
Although the characteristic values obtained for density $\left(478.8 \mathrm{~kg} \cdot \mathrm{m}^{-3}\right.$ and $\left.452.8 \mathrm{~kg} \cdot \mathrm{m}^{-3}\right)$ and modulus of elasticity $\left(14,022.7 \mathrm{~N} \cdot \mathrm{mm}^{-2}\right.$ and $\left.11,275.6 \mathrm{~N} \cdot \mathrm{mm}^{-2}\right)$ also exceed the requirements of grade $\mathrm{C} 27$, the values of bending strength $\left(26.4 \mathrm{~N} \cdot \mathrm{mm}^{-2}\right.$ and $\left.14.1 \mathrm{~N} \cdot \mathrm{mm}^{-2}\right)$ do not (Tables 3 and 4 ).

The large difference between the characteristic values $\left(26.4 \mathrm{~N} \cdot \mathrm{mm}^{-2}\right.$ and $\left.478.8 \mathrm{~kg} \cdot \mathrm{m}^{-3}\right)$ and the 5 -percentile values $\left(37.7 \mathrm{~N} \cdot \mathrm{mm}^{-2}\right.$ and $\left.544.1 \mathrm{~kg} \cdot \mathrm{m}^{-3}\right)$ of visual grade ME- 1 (Table 3) and the characteristic values $\left(14.1 \mathrm{~N} \cdot \mathrm{mm}^{-2}\right.$ and $\left.452.8 \mathrm{~kg} \cdot \mathrm{m}^{-3}\right)$ and the 5 -percentile values $\left(20.2 \mathrm{~N} \cdot \mathrm{mm}^{-2}\right.$ and $\left.514.5 \mathrm{~kg} \cdot \mathrm{m}^{-3}\right)$ of visual grade ME-2 (Table 4) is due to the penalisation imposed by EN 384 [9] when only one sub-sample is used. Standard EN 384 [9] penalises density and bending strength with a factor to adjust for the number of subsamples $k_{n}$ of 0.88 and 0.70 , respectively. As a result, wood in visual grades ME- 1 and ME-2 cannot be assigned to a class higher than C24 or C14, respectively.

The strength class of grade ME- 1 is similar to that of the other Spanish pines, which range from C24 to C30. However, grade ME-2 is slightly lower than the other Spanish pines assigned to C18 (Table 7). If future studies manage to use a higher number of pieces, from various provenances, the penalisation factor will likely be lower, resulting in a much higher strength class.

Table 7. Spanish pine strength classes in standard EN $1912[16,17]$.

\begin{tabular}{cccccc}
\hline Class & Canary Island Pine & Salzmann Pine & Scots Pine & Radiata Pine & Maritime Pine \\
\hline ME-1 & C24 & C30 & C27 & C24 & C24 \\
\hline ME-2 & C14 & \multicolumn{3}{c}{ C18 } \\
\hline
\end{tabular}

The influence of density on mechanical properties is widely known [18-24] and has been used as a classifying parameter for structural properties [25].

The present study also shows the influence of density on mechanical properties, although it was not possible to fully verify the direct linear proportionality because of the low determination coefficients.

Growth ring width shows greater variability in grade ME-2 than in grade ME- 1 (Table 5). This is seen in the higher standard deviation $(1.23 \mathrm{~mm}$ for grade ME- 2 and $0.77 \mathrm{~mm}$ for grade ME- 1 ) and range $(6.19 \mathrm{~mm}$ for grade ME-2 and $4.05 \mathrm{~mm}$ for grade ME-1). The maximum growth ring width value $(5.13 \mathrm{~mm}$ ) is slightly higher than the specification in UNE 56544 [7] (Table 1) for grade ME-1 of Salzmann pine $(5 \mathrm{~mm})$ and lower than the specification for the same grade of maritime pine $(8 \mathrm{~mm})$.

Because of this, a limit of $6 \mathrm{~mm}$ is proposed for Canary Island pine as the maximum growth ring width for grade ME-1; that is, a value between Salzmann pine and maritime pine. This limit is slightly conservative, because the maximum ring width recorded was $5.13 \mathrm{~mm}$. However, it is an initial proposal and could be altered by future research using a larger number of samples. For grade ME-2, no limit is proposed for ring width, as occurs with the four other pine species included in UNE 56544 [7].

Growth ring width has a statistically significant influence on MOR and MOE for a confidence level of $95 \%$, although it was not possible to fully verify the inverse linear proportionality because of the low determination coefficients. This relation was also reported in Pinus caribaea Morelet by Gonçalez et al. [26], who similarly included density. Other studies associated the influence of density and growth rings together, e.g., in Pinus sylvestris and Picea abies (L.) H.Karst. [27,28] with positive results in both modulus of elasticity and bending strength. Hanhijarvi et al. $[29,30]$ found very good correlation coefficients using a combination of density and ring width to predict MOE.

This variable was also studied in combination with density by Fernández-Golfín and Díez [25], who concluded that although ring width has an influence on the mechanical properties, it has less influence than density.

The number of growth rings has a statistically significant influence on MOR and MOE for a confidence level of $95 \%$. This influence can also be deduced from density, because large growth rings in softwoods indicate a lower proportion of latewood and, therefore, lower density [24]. This relation was also observed in Pinus taeda L., in which MOR and MOE increase with the number of growth rings [31]. 
Resinous wood is a characteristic feature of this species. Although its anatomical structure presents a high abundance of resin canals, more than in other pines, this does not appear sufficient to explain the high resin content of this wood. The metabolic pathway of the ray parenchyma cells through the cross-field pits appears to be an additional mechanism in contributing resin [1].

The presence of resinous wood in this pine had a significantly negative association with the mechanical properties MOR and MOE, even though resinous wood is denser than non-resinous wood. While this may appear to contradict the direct relation between mechanical properties and density, it must be considered that resinous wood corresponds more to a non-porous than a porous material and has different behaviour. Moreover, in trees with the age of those in this study, resinous wood is concentrated near the pith and therefore in the corewood, which has lower mechanical characteristics. Studying mature trees with resinous corewood and outerwood is the only way to determine the influence of resin on the mechanical properties of both types of wood. Unfortunately, it is almost impossible to obtain a representative sample of resinous outerwood, because it occurs only in very old trees, and all the old trees of this species are located in protected natural areas.

Very few studies have compared the mechanical properties of resinous and non-resinous wood of a single species. García-Iruela et al. [32] studied the influence of resin formation in Pinus pinaster wood due to tapping. Unlike the present study, they found that the resinification process improved the mechanical properties. This discrepancy could be due to two essential differences between the studies. Firstly, resin formation in the trees studied by García-Iruela et al. [32] was caused artificially by tapping, while in the present study, it occurred naturally; and secondly, García-Iruela et al. [32] used oriented small clear test pieces, whereas the pieces in the present study were large, not oriented and contained defects.

This study was conducted on wood from thinning operations and the best individuals were left standing. The wood of the trees remaining in the forest is likely to have better mechanical characteristics because the trees have a better form, but thinning will result in wider growth rings and therefore somewhat lower wood density, which could decrease the mechanical properties.

This work is a first study to advance the characterisation of Canary Island pine sawn timber. Further studies using larger pieces of sawn timber and wood from other provenances will help to increase the value of other products of primary and secondary processing, ensuring that thinning as part of sustainable management of pines reforested on the island of Tenerife will boost jobs and industry in the region.

\section{Conclusions}

The Canary Island pine wood visually graded in this study as ME- 1 is assigned to strength class C24, with similar values to $P$. radiata and P. pinaster, and the wood graded as ME-2 is assigned to strength class $\mathrm{C} 14$, with slightly lower ME-2 visual strength grading values than pines from mainland Spain.

To include the visual strength grade of Canary Island pine wood in the corresponding standards, a $6 \mathrm{~mm}$ growth ring width limit is proposed for class ME-1, and no limit is proposed for class ME-2.

Density, number of growth rings, growth ring width and presence of resinous wood have a significant influence, for a confidence level of $95 \%$, on mechanical properties MOR and MOE.

Silvicultural treatments to improve and conserve the reforested pine forests on the island of Tenerife pave the way for more profitable use of Canary Island pine, helping to create jobs and industries and ensuring sustainable forest management. 
Author Contributions: Conceptualization, L.G.E., P.d.P., V.P.B., J.A.P. and E.P.C.; data curation, F.G.F. and A.G.-I.; formal analysis, L.G.E., P.d.P., F.G.F. and F.A.; funding acquisition, V.P.B.; investigation, L.G.E., P.d.P., F.G.F., A.G.-I. and J.C.d.P.; methodology, F.G.F., A.G.-I., J.C.d.P., V.P.B., J.A.P., E.P.C. and F.A.; project administration, P.d.P., J.A.P. and E.P.C.; resources, V.P.B., J.A.P. and E.P.C.; software, F.G.F. and A.G.-I.; supervision, L.G.E. and F.A.; validation, L.G.E., P.d.P., V.P.B., J.A.P., E.P.C. and F.A.; visualization, L.G.E., V.P.B. and F.A.; writing-original draft, L.G.E., P.d.P., F.G.F., A.G.-I. and J.C.d.P.; writing-review and editing, V.P.B., J.A.P. and E.P.C. All authors have read and agreed to the published version of the manuscript.

Funding: This research was funded by the Servicio Técnico de Planificación y Proyectos Forestales of the Área de Sostenibilidad, Medio Ambiente, Aguas y Seguridad, Cabildo Insular de Tenerife.

Acknowledgments: The authors are grateful to the Cabildo Insular de Tenerife for its initiative in developing this study.

Conflicts of Interest: The authors declare no conflict of interest.

\section{References}

1. Esteban, L.G.; Gasson, P.; Climent, J.M.; de Palacios, P.; Guindeo, A. The wood of Pinus canariensis and its resinous heartwood. IAWA J. 2005, 26, 69-77. [CrossRef]

2. Esteban, L.G. Serie Documental El Bosque Protector: Tenerife-Corona Forestal. 2019. Available online: https: //www.rtve.es/alacarta/videos/el-bosque-protector/bosque-protector-tenerife-corona-forestal/5387738/ (accessed on 16 April 2020).

3. Oliva, A.G.; Pulgar, F.P. Características Físico-Mecánícas de las Maderas Españolas; Instituto Forestal de Investigaciones y Experiencia (IFIE): Madrid, Spain, 1967.

4. Rodríguez, C.; Vergara, E. Propiedades físicas y mecánicas de la madera de Pinus canariensis crecido en el secano de la Región del Maule, Chile. Bosque (Valdivia) 2008, 29, 192-196. [CrossRef]

5. Guindeo, A.; Esteban, L.G.; Peraza, F.; Arriaga, F.; Kasner, C.; Medina, G.; de Palacios, P.; Touza, M. Especies de Madera Para Carpintería, Construcción y Mobiliario; AITIM: Madrid, Spain, 1997.

6. Montero, G.; Vallejo, R.; Ruiz-Peinado, R. Fototeca Forestal Española INIA. 2007. Available online: http: //www.inia.es/fototeca (accessed on 16 April 2020).

7. Spanish Standard. UNE 56544. Visual Grading for Structural Sawn Timber. Coniferous Timber; Asociación Española de Normalización (AENOR): Madrid, Spain, 2011.

8. European Standard. EN 338. Structural Timber. Strength Classes; European Committee of Standardization (CEN): Brussels, Belgium, 2016.

9. European Standard. EN 384+A1:2018. Structural Timber-Determination of Characteristic Values of Mechanical Properties and Density; European Committee of Standardization (CEN): Brussels, Belgium, 2016.

10. European Standard. EN 1309-1. Round and Sawn Timber. Method of Measurement of Dimensions. Part 1: Sawn Timber; European Committee of Standardization (CEN): Brussels, Belgium, 1997.

11. European Standard. EN 1309-3. Round and Sawn Timber. Methods of Measurements. Part 3: Features and Biological Degradations; European Committee of Standardization (CEN): Brussels, Belgium, 2018.

12. European Standard. EN 13183-1. Moisture Content of a Piece of Sawn Timber. Part 1: Determination by Oven Dry Method; European Committee of Standardization (CEN): Brussels, Belgium, 2002.

13. European Standard. EN 13183-1/AC. Moisture Content of a Piece of Sawn Timber. Part 1: Determination by Oven Dry Method; European Committee of Standardization (CEN): Brussels, Belgium, 2003.

14. European Standard. EN 408+A1:2012. Timber Structures. Structural Timber and Glued Laminated Timber. Determination of Some Physical and Mechanical Properties; European Committee of Standardization (CEN): Brussels, Belgium, 2010.

15. European Standard. EN 14358. Timber Structures. Calculation and Verification of Characteristic Values; European Committee of Standardization (CEN): Brussels, Belgium, 2016.

16. European Standard. EN 1912. Structural Timber. Strength Classes. Assignment of Visual Grades and Species; European Committee of Standardization (CEN): Brussels, Belgium, 2012.

17. European Standard. EN 1912/AC. Structural Timber. Strength Classes. Assignment of Visual Grades and Species; European Committee of Standardization (CEN): Brussels, Belgium, 2013.

18. Zhang, S.Y. Mechanical properties in relation to specific gravity in 342 Chinese woods. Wood Fiber Sci. 1994, 26, 512-526. 
19. Zhang, S.Y. Wood specific gravity mechanical property relationship at species level. Wood Sci. Technol. 1997, 31, 181-191. [CrossRef]

20. Forest Products Laboratory (FPL). Wood Handbook. Wood as an Engineering Material. General Technical Report FPL-GTR-113; Forest Products Laboratory, USDA Forest Service: Madison, WI, USA, 1999.

21. Kiaei, M. Anatomical, physical and mechanical properties of eldar pine (Pinus eldarica Medw.) grown in the Kelardasht region. Turk. J. Agric. For. 2011, 35, 31-42. [CrossRef]

22. Zhou, C.; Chiu, Y.H.; Gong, M. Within-stem variation in wood properties of red pine (Pinus resinosa Ait.). Wood Fiber Sci. 2012, 44, 412-421.

23. Miyoshi, Y.; Kojiro, K.; Furuta, Y. Effects of density and anatomical feature on mechanical properties of various wood species in lateral tension. J. Wood Sci. 2018, 64, 509-514. [CrossRef]

24. Pamerleau-Couture, E.; Rossi, S.; Pothier, D.; Krause, C. Wood properties of black spruce (Picea mariana (Mill.) BSP) in relation to ring width and tree height in even- and uneven-aged boreal stands. Ann. For. Sci. 2019, 76, 43. [CrossRef]

25. Fernández-Golfín, J.I.; Díez, M.R. Influencia de la anchura del anillo de crecimiento en la densidad y otras propiedades físico-mecánicas de la madera estructural de diversas especies. Investig. Agrar. Sist. Recur. For. 1994, 3, 211-219.

26. Gonçalez, J.C.; Santos, N.; da Silva, F.G.; Souza, R.S.; de Paula, M.H. Growth ring width of Pinus caribaea and its relationship with wood properties. Sci. For. 2018, 46, 670-678. [CrossRef]

27. Hautamaki, S.; Kilpelainen, H.; Verkasalo, E. Factors and models for the bending properties of sawn timber from Finland and North-Western Russia. Part I: Norway spruce. Balt. For. 2013, 19, 106-119.

28. Hautamaki, S.; Kilpelainen, H.; Verkasalo, E. Factors and models for the bending properties of sawn timber from Finland and North-Western Russia. Part I: Scots pine. Balt. For. 2014, 20, 142-156.

29. Hanhijarvi, A.; Ranta-Maunus, A.; Turk, G. Potential of Strength Grading of Timber with Combined Measurement Techniques. Report of the Combigrade_Project_Phase 1; VTT Publications: Espoo, Finland, 2005.

30. Hanhijarvi, A.; Ranta-Maunus, A. Development of Strength Grading of Timber Using Combined Measurement Techniques. Report of the Combigrade_Project_Phase 2; VTT Publications: Espoo, Finland, 2008.

31. Jeong, G.Y. Relationship between anatomical and mechanical properties of loblolly pine (Pinus taeda). For. Prod. J. 2013, 63, 47-53. [CrossRef]

32. Garcia-Iruela, A.; Esteban, L.G.; de Palacios, P.; García-Fernández, F.; Torres, A.D.; Iriarte, E.V.; Simón, C. Resinous wood of Pinus pinaster Ait.: Physico-mechanical properties. BioResources 2016, 11, 5230-5241. [CrossRef]

(C) 2020 by the authors. Licensee MDPI, Basel, Switzerland. This article is an open access article distributed under the terms and conditions of the Creative Commons Attribution (CC BY) license (http://creativecommons.org/licenses/by/4.0/). 